Indonesian Aquaculture Journal, 15 (2), 2020, 93-102

Available online at: http://ejournal-balitbang.kkp.go.id/index.php/iaj

\title{
COMBINATION VACCINES AGAINST KOIHERPES VIRUS AND Aeromonas hydrophila CO-INFECTION IN KOI AND COMMON CARP
}

\author{
Angela Mariana Lusiastuti*\#, Hessy Novita*), Lila Gardenia*), Taukhid*, and Habil Sven M. Bergmann**) \\ *) Research Institute for Freshwater Aquaculture and Fisheries Extension \\ Jl. Sempur No. 1, Bogor, Indonesia \\ *N Friedrich-Loeffler-Institut, Federal Research Institute for Animal Health, Greifswald-Insel Riems, Germany \\ Südufer 10, 17493 Greifswald, Germany
}

(Received: October 11, 2019; Final revised: October 13, 2020; Accepted: October 13, 2020)

\begin{abstract}
Co-infections occur when hosts are infected by two or more pathogens, either simultaneous or as a secondary infection. This research aimed to determine the best compositions of vaccine combinations and their protective efficacies against pathogens co-infection. This research was conducted in two stages. Firstly, surveys were conducted in three research areas: infected, high risk of infection, and virus free areas. Samples (three to five fish per pool) were collected from three fish farms per area. The basic antibody titer of fish from each farm was checked before and after vaccination as well as after the virus challenge in combination with the PCR result. The second stage of the research was conducted in the laboratory. Carp and koi fish were used to determine optimal vaccine combination and dosage for oral application. The results of this research showed that combination of KHV: Aeromonas hydrophila vaccines in the ratio of 1:2 and vaccine volume of $3 \mathrm{~mL}$ via the oral application gave higher titer antibody and efficacy against KHV and A. hydrophila. In conclusion, the combined vaccine offers an effective means of preventing the diseases, decreasing fish mortality, and simplifying the immunization schedule, which will eventually increase the overall health of farmed fish and benefit fish farmers and service extension officers. This research recommends that further development of the combined vaccines should be carried out, for example, overcoming the technical difficulties in its manufacturing.
\end{abstract}

\section{KEYWORDS: KHV; Aeromonas hydrophila; combination vaccine; common carp; koi}

\section{INTRODUCTION}

Common carp (Cyprinus carpio L.) is the most widely farmed fish for human consumption, mainly in Asia and Europe. On the contrary, koi (C. carpio koi) are reared primarily as an ornamental fish or competition events especially in Indonesia and Japan. Intensive culture of common carp and large-scale market distribution of live koi, often lacking health certifications, have contributed to the global spread of KHV disease (KHVD) which responsible for mass mortalities of carp related fish (Haenen et al., 2004).

In Indonesia, the first outbreak of KHVD was reported in East Java in 2002 (Sunarto et al., 2002). Since then, it has spread rapidly throughout Java Island, Bali,

\footnotetext{
\# Correspondence: Research Institute for Freshwater

Aquaculture and Fisheries Extension.

Jl. Sempur No. 1, Bogor, Indonesia

Tel. + 622518313200

E-mail: Iusiastuti_61@yahoo.co.id
}

Southern part of Sumatra, East Kalimantan, and Central Sulawesi. The KHVD caused high mortality $(80 \%$ $95 \%$ to koi and common carp with estimated economic losses up to US\$15M in 2003 (Sunarto \& Cameron, 2005).

Co-infection occurs when hosts are infected by two or more different pathogens, either simultaneous or as a secondary infection meaning that two or more infectious agents were present in the same host (Kotob et al., 2016). During episodes of co-infection, the interactions between the infectious agents yield to synergism or antagonism conditions: concentration of one or both pathogens may be increased or suppressed, and one pathogen may be increased, but the other did not appear (Cox, 2001). Natural co-infection between Aeromonas veronii and Tilapia Lake Virus (TiLV) were found as A. veronii concurrently isolated with TiLV from the diseased tilapia (Nicholson et al., 2017). According to Surachetpong et al. (2017), multiple bacteria infec- 
tion, including Flavobacterium, Streptococcus, and Aeromonas were also found in TiLV infected fish. Interactions of $A$. veronii and TiLV might be synergistic, resulted in enhanced of pathogens infection and increased severity of the disease. In KHV infection, the presence of other pathogen such as Aeromonas hydrophila are relatively common, which induced higher mortality. Aeromonas spp. commonly associated with other diseases in warm water fish. It is found in almost all freshwater environments, sediment, do mestic tap water, sewage, and part of normal flora on the skin.

Fish mortality caused by KHV infection ranged up to $60 \%$ with predominantly marketable-size fish were affected. Infected fish exhibiting clinical signs with typical systemic bacterial infection. Aeromonas hydrophila infection occurs secondarily to preexisting diseases, weakened immune system, injury or ulcer or following periods of low oxygen, high ammonia, extreme temperature, or other forms of stress (crowding). Diseased fish are often additionally infected with other bacteria such as Flavobacterium columnare and Edwardsiella ictaluri (Lusiastuti et al., 2012). Based on the report of Schmid et al. (2016) who investigated the efficacy of three inactivated KHV antigens in common carp, we constructed a combined vaccine of $\mathrm{KHV}$ and $\mathrm{A}$. hydrophila. The attenuated KHV and its potential use as a vaccine candidate have been described in the International Patent WO 2004/061093 Al. However, this combined vaccine candidate hides a potential danger. Viral attenuation as a consequence of random mutations that occurred during viral replication in vitro via serial passage in cell culture. Consequently, the character of the attenuation is largely unknown and reversion to a pathogenic phenotype cannot be excluded in some circumstances.

Combination vaccines that protect against different infectious diseases can help to simplify the current immunization schedule. The other benefits of combination vaccines include decreased number of potentially harmfull procedures such as handling and injection which is more convenience for fish and also reduced vaccination costs for fish farmers. Other benefits of using combination vaccines are decreased infection risk from site of vaccine injection and potentially improved fish health record and tracking. The benefit of using a combination vaccine in fish health management will significantly reduce the overall cost of production associated with fewer vaccination process. For example, by using a combination vaccine, fish are only vaccinated once instead of twice or more by conventional vaccines. The combination of two different antigens at the same time will result in differences in antigen processing which activate different signaling pathways by affecting the T-immune cell response. Hopefully, the combinnation vaccine between KHV and A. hydrophila can induce a stronger and protective antibody response. According to Monaghan et al. (2016), a combination vaccine of Chlamydia suis and $\mathrm{C}$. trachomatis simultaneously delivered antigens which improved the immunogenicity and the protective efficacy in pigs. Moreover, the combination vaccine can potentiate and broaden pig's immune response. The aim of this research was to established the best composition and dosage of the combination vaccine, and its efficacy for protection against $A$. hydrophila and koiherpes virus.

\section{MATERIALS AND METHODS}

\section{Fish and Fish Samples}

- This research was conducted in two stages. Firstly, surveys were done in the field by dividing the sampling area into three locations: infected, a high risk of infection, and virus free areas. The surveys were conducted in Citayam as the infected area, Ciganjur as the high-risk area and Ciseeng as the virus free area. The samples were taken before vaccination, after vaccination and during challenge tests. Fish were brought to the wet lab in Depok for challenge test. Samples (three to five fish per pool) were collected from the three fish farms in each area. The antibody titer of fish from each farm was checked before vaccination, after vaccination and after challenge test with koiherpes virus in combination with the results of PCR analysis (Bergmann et al., 2006).

- The second stage of the research was conducted in the laboratory. In total, 2,000 carp and koi, respectively; were used in the experiment. As much as 1,000 carps were used to obtain the best combination of the vaccine; and 1,000 koi were used to find the best dosage for oral application. Prevaccinated fish were taken randomly and tested for KHV free by PCR analysis (Yuasa et al., 2005) to ensure the absence of the virus.

- Koi with an initial weight of $10 \mathrm{~g}$, and carp with an initial length of 5-7 cm were obtained from a local farm in Depok (West Java) and were used in the experiment. They were kept in a $2 \mathrm{~m} \times 2 \mathrm{~m}$ concrete pond. A commercial feed with crude protein content adjusted for fish weight was supplied ad libitum twice a day (morning and afternoon).

\section{Vaccines Preparation}

- Vaccines used in this study were: (1) heat inactivated $\mathrm{KHV}$ isolate BJMN-2, and (2) formalin inactivated bacterium A. hydrophila isolate AHL0905-2. 
These bacterial and virus isolates were part of the collections of the Research Institute for Freshwater Aquaculture and Fisheries Extension Bogor Indonesia obtained from natural disease outbreaks. Both isolates were used for the challenge test. Preparation for virus inactivation was performed according to the methods of Nakajima et al. (1999) and Yasumoto et al. (2006) with slight modifications.

- Supernatant homogenate were obtained from tissues of KHV infected fish. One gram of gills, kidneys and spleen tissues (3:1:1 weight/weight) were homogenized and then mixed with sterile PBS until it reached 50x dilution. After that, the suspension was centrifuged at $15,000 \mathrm{rpm}$ at $4^{\circ} \mathrm{C}$ for 15 minute and filtrated through $0.45 \mu \mathrm{m}$ filter (MF-Millipore ${ }^{\mathrm{TM}}$ ). Supernatant homogenate was inoculated into koi fin-1 cell (KF-1 cells) in 2\% Leibovits-15 medium for one hour at $25^{\circ} \mathrm{C}$ for virus absorption. The virus was then ready to be harvested when the cytopathic effect had reached approximately $80 \%$ The cells and medium containing virus were poured into a $500 \mathrm{~mL}$ schott bottle and ready for the vaccine preparation by heat-inactivated at $60^{\circ} \mathrm{C}$ for four hours then it was kept at $86^{\circ} \mathrm{C}$ until used (Bergmann et al., 2017).

Determination of $50 \%$ tissue culture infective dose $\left(\mathrm{TCID}_{50}\right)$ was performed using a 96-well microwell flask. The calculation of $\mathrm{TCID}_{50}$ was based on the Reed \& Muench method (1938): TCID50 = $(50 \% \%$ positive dilution below $50 \%$ / (\%positive dilution above $50 \% \%$ positive under $50 \%$.

- A. hydrophila vaccine preparation was performed as follows: the bacteria were characterized and fulfilled the Koch's Postulates. Pure bacteria were used as the vaccine seed. The vaccine was produced using the commercial tryptic soy agar (TSA) (Merck, Germany) sterile which was poured into $10 \mathrm{~cm}$ petridishes. A total of $0.2 \mathrm{~mL}$ of bacterial suspension with a density of $10^{11} \mathrm{cfu} / \mathrm{mL}$ were transferred onto the surface of agar plates using L-glass. Incubation was carried out for 24 hours at a temperature of $27 \pm 1^{\circ} \mathrm{C}$. Harvesting was performed by dry system, using disposable ose, and bacterial growth (grazing rate) with efficiency above $99 \%$ Inactivation process for vaccine preparation was carried out by formalin-inactivation using $1 \%$ formaldehyde solution (Merck, Germany) stirred with magnetic stirrer for two hours. Then, vaccine stock solution was kept at $4{ }^{\circ} \mathrm{C}-8^{\circ} \mathrm{C}$ for 24-28 hours. The bacteria harvested from the three petri dishes was dissolved in $100 \mathrm{~mL}$ of $0.85 \%$ phosphate buffer saline (Merck, Germany) and bacterial concentration was $10^{11} \mathrm{cfu} / \mathrm{mL}$. The whole process of vaccine preparation was done aseptically in accordance to Good Laboratory Practices (GLP).

Each treatment was proceeded with 200 fish with four replication (50 fish per aquaria)

\section{Treatment 1:}

Vaccination was conducted by immersion with a dose of $10 \mathrm{~mL} \mathrm{liter}^{-1}$. Carp $(n=10)$ were immersed in the suspension.

The vaccination was carried out of five treated and untreated groups:

A : proportional combination vaccine (1a:1b, v/ v), and challenge test

B : non-proportional combination vaccine (1a:2b, $\mathrm{v} / \mathrm{v})$, and challenge test

$C$ : non-proportional combination vaccine (2a:1b, $\mathrm{v} / \mathrm{v})$, and challenge test

$D$ : no vaccination (negative control), without challenge test

E : no vaccination (positive control), PBS injec tion, and challenge test

\section{Treatment 2:}

The best in vaccine from treatment- 1 was used in treatment-2 with oral application. The five groups were treated with:
A : vaccine dose $1 \mathrm{~mL} \mathrm{~kg}^{-1}$ food, and challenge test
$B$ : vaccine dose $2 \mathrm{~mL} \mathrm{~kg}^{-1}$ food, and challenge test
C : vaccine dose $3 \mathrm{~mL} \mathrm{~kg}^{-1}$ food, and challenge test
D : no vaccination (negative control), without challenge test
E : no vaccination (positive control), PBS injec tion, and challenge test

KHV and A. hydrophila challenge tests were performed on day $21^{\text {st }}$ and $35^{\text {th }}$ post vaccination. The KHV challenge test was performed by cohabitation, using KHV infected fish which was previously injected intraperitoneally with $0.2 \mathrm{~mL}$ fish $^{-1} \mathrm{KHV}$ and $A$. hydrophila challenge test was carried out by intraperitonial injection with $10^{8} \mathrm{CFU} \mathrm{mL}{ }^{-1}$ of A. hydrophila.

\section{The Evaluation of Test Parameter:}

The evaluation based on antibody titer were conducted by direct agglutination assay for $A$. hydrophila and enzyme linked immune sorbent assay (ELISA) for KHV (Bergmann et al., 2017). 


\section{Determination of The Antibody Titer:}

After $2^{\text {nd }}$ and $3^{\text {th }}$ weeks post-vaccination and $5^{\text {th }}$ and $6^{\text {th }}$ weeks after-challenge test, 15 fish from each group were anaesthetized for blood sampling. After whole blood phagocytosis index were measured, plasma was separated and stored at $-20^{\circ} \mathrm{C}$ until used for ELISA and direct agglutination assays.

- The direct agglutination assay was performed to detect antibody level against A. hydrophila. The procedure proposed by Roberson (1990) measured the antibody level at $2^{\text {nd }}$ and $3^{\text {th }}$ weeks post-vaccination and continued at $5^{\text {th }}$ and $6^{\text {th }}$ weeks after challenge test. ELISA assay was employed to confirm the levels of specific antibodies against KHV in all serum samples. Phagocytosis index (IF) was evaluated by using the method of Zhang et al. (2008) with slight modification.

\section{Data Analysis}

The result of phagocytosis index and antibody titer from survey were analyzed descriptively.

\section{RESULTS AND DISCUSSION}

The fish sera from each farm were checked and monitored by using ELISA assay before vaccination (Table 1). In Table 1, the infected area was classified into two separate fish groups, where group-I showed $50 \%$ morbidity and group-II showing no morbidity. In group-I, the antibody titer value was approximately 1:600 and $20 \%$ of positive by PCR assay. The mild or late infection with no clinical signs area, the value of antibody titers were 1:300 with KHV detection of $40 \%$ by PCR assay.
Despite fish group-II and III being in the areas close to the infected area, none of the samples was KHV-positive by PCR assay, the antibody titers in the mild or late infections were 1:300 and PCR assay gave positive signals in $10 \%$ of the samples. No KHV was detected in $90 \%$ of the fish samples by using PCR. The areas catego rized as no KHV infection (clean area) had $100 \%$ negative test results, both using ELISA and PCR assay.

Table 2 shows that no significant difference between the antibody titer in mild or late infection fish and the virus-negative fish in group-I, nor it was possible, by their antibody titer, to differentiate between those fish which had undergone clinical disease and those which had a persistent or latent infection. Table 2 showsd that the antibody titer after vaccination and challenge test was higher compared to prior vaccination.

Figure 2 shows the antibody titers after vaccination compared with the negative controls. Vaccine B, which consisted of one part of KHV vaccine and two parts of $A$. hydrophila vaccine gave a higher antibody titer in the first week post-vaccination. The assays showed an increase in antibody titers at the first month post-vaccination and a decrease at the second months.

Before and after KHV-Aero vaccination, the vaccine dose of $3 \mathrm{~mL}$ had increased the antibody titer higher than the other treatments until the $3^{\text {th }}$ week and then decreased at the $4^{\text {th }}$ week.

The KHV challenge test was performed at $5^{\text {th }}$ week post-vaccination (Figure 4), which caused the increased in antibody titer of fish group with $3 \mathrm{~mL}$ vo-

Table 1. KHV antibody titers and virus detection by using PCR assay from groups of fish in infected and non-infected fish farms before vaccination

\begin{tabular}{lccc}
\hline \multirow{2}{*}{ Area } & \multicolumn{3}{c}{ Antibody titers value (PCR detection \%) } \\
\cline { 2 - 5 } & $\begin{array}{c}\text { Severe infection } \\
\text { (positive PCR) }\end{array}$ & $\begin{array}{c}\text { Mild or late infection } \\
\text { (positive PCR) }\end{array}$ & $\begin{array}{c}\text { No clinical sign } \\
\text { (negative PCR) }\end{array}$ \\
\hline Infected area: & & & \\
Group-I: 50\%morbidity (Citayam II, Bogor) & $1: 600(20)$ & $1: 300(40)$ & $1: 300(40)$ \\
Group-II: 0\%morbidity (Citayam I, Depok) & 0 & $1: 300(20)$ & $1: 300(80)$ \\
\hline High risk area: & 0 & $1: 300(10)$ & $0(90)$ \\
Group-III (Ciganjur) & 0 & 0 & $0(100)$ \\
\hline Virus free area: & 0 & & \\
Group-IV (Ciseeng) & &
\end{tabular}


Table 2. The mean of KHV antibody titers and PCR detection of KHV from fish groups with and without infection after vaccination and challenge test

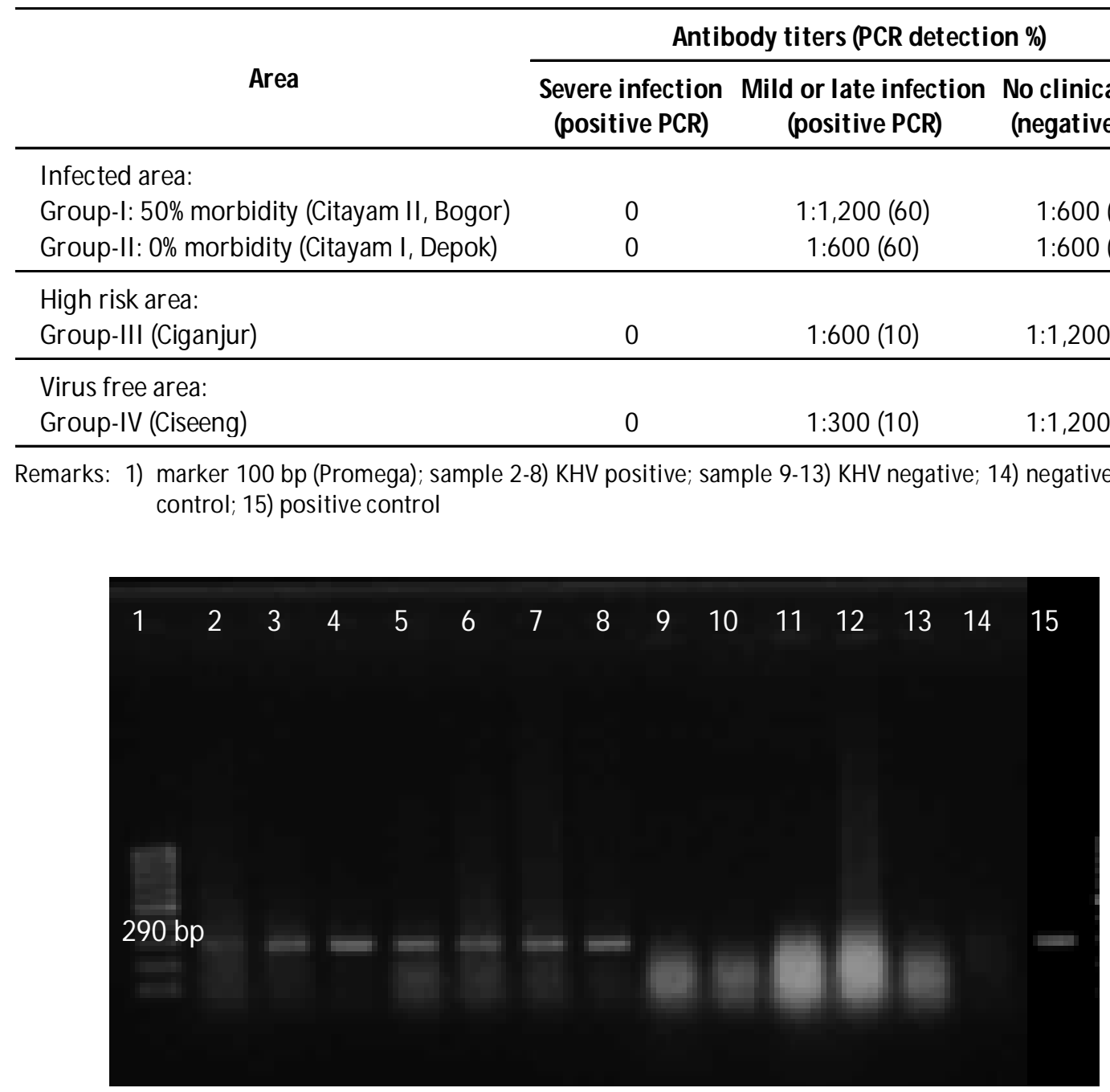

Figure 1. KHV detection by PCR.

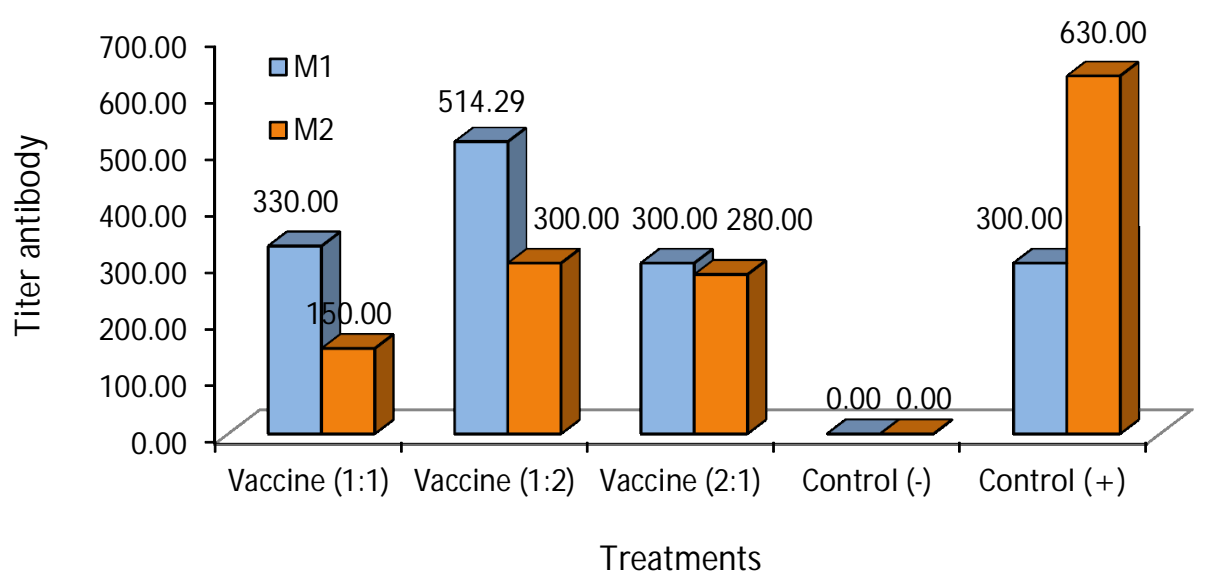

Remarks: Vaccine A (1:1); vaccine B (1:2), vaccine C (2:1); D (control negative); E (control positive); at $1^{\text {st }}$ month (M1); $2^{\text {nd }}$ month (M2) post-vaccination

Figure 2. Antibody titer after vaccination at first month (M1) and $2^{\text {nd }}$ month (M2) post-vaccination $(n=60)$ with different compositions of the KHV-Aero vaccine. 


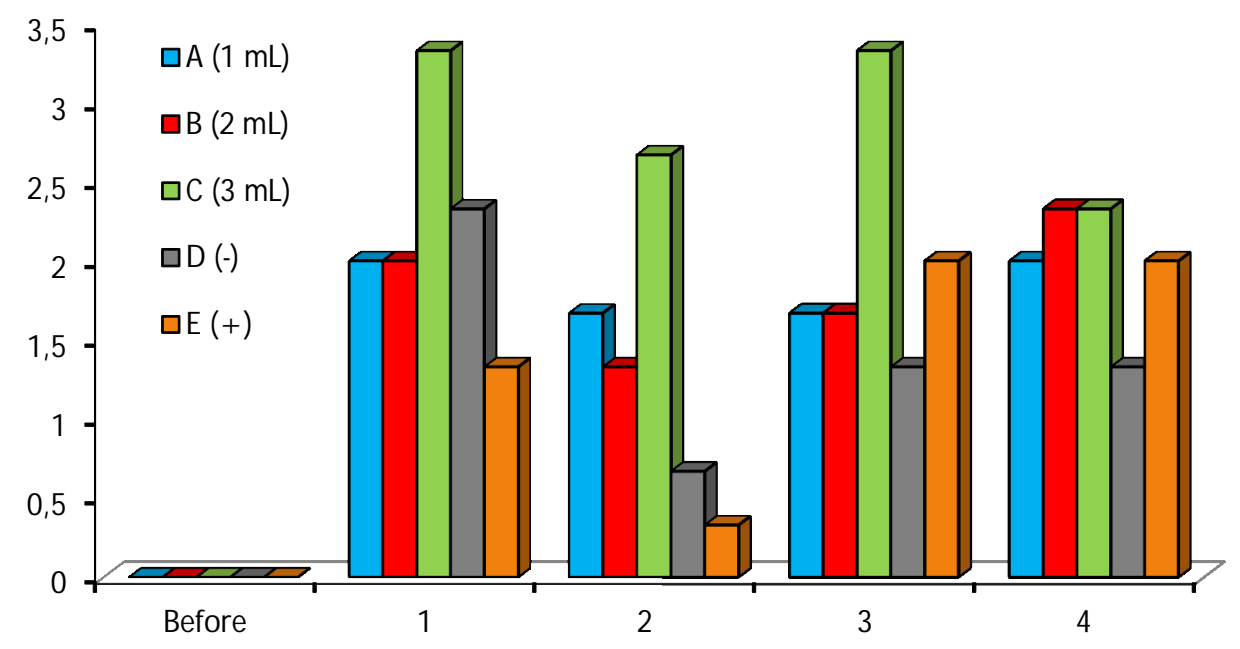

Weeks post vaccination (treatment-II)

Figure 3. Antibody titer before and after KHV-Aero vaccination (treatment-2, oral vaccination).

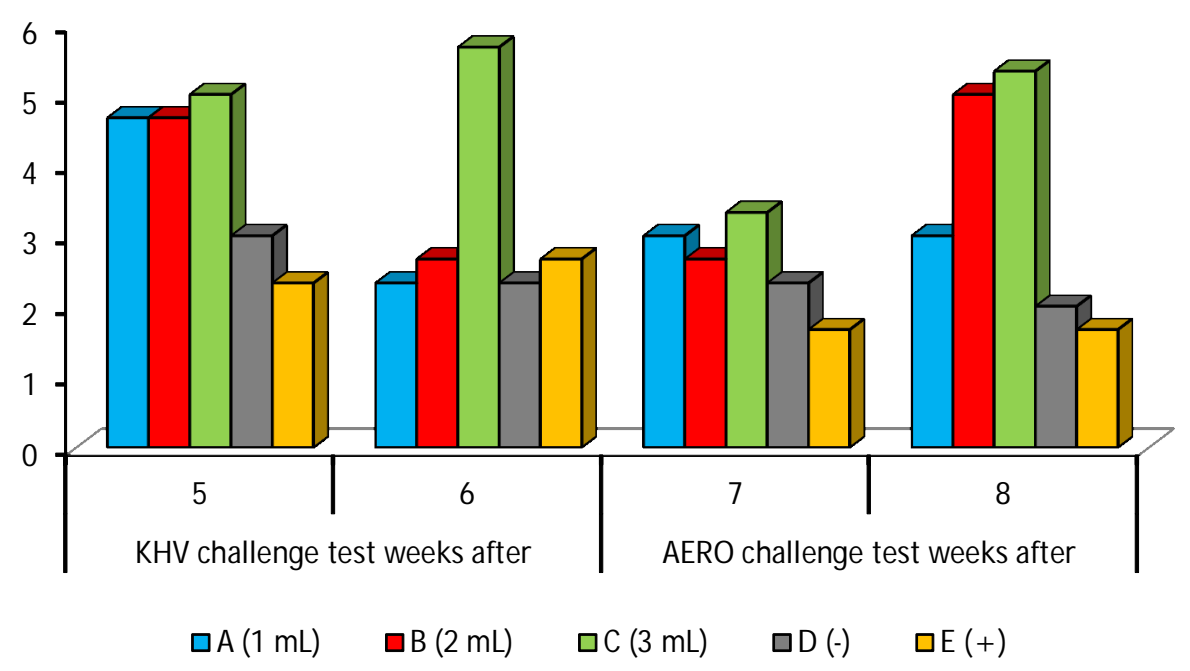

Figure 4. Antibody titers against KHV and A. hydrophila after KHV and A. hydrophila challenge test.

lume-dosage at $6^{\text {th }}$ week and decreased in antibody level at $7^{\text {th }}$ week post-vaccination. Surprisingly, after challenge test with $A$. hydrophila, antibody titers against KHV increased again at $8^{\text {th }}$ week post-vaccination. This result is in accordance with Monaghan et al. (2016) that a combination vaccine can potentiate the immune response to $A$. hydrophila and induce a stronger anti-KHV antibody level.

Figure 5 shows phagocytosis index between the vaccinated and non-vaccinated groups. In vaccinated fish, the phagocytosis indexes tend to be lower than in non-vaccinated fish.
Koiherpes virus (KHV) is a latent or persistent infection, but in a population of fish that has never been infected, it can cause acute disease with more than $90 \%$ mortality in carp and koi, both seed and adult (van Regenmortel et al., 2000). In aquatic environment, fish were exposed to infectious mixed pathogens of macro or micro-organisms. There is a greater risk of mass mortality if a fish population is infected by either a single or multiple pathogens. It is currently unknown whether the presence of a pathogen is a burden to other pathogens or the mortality rate of the host is increased in coinfection com- 


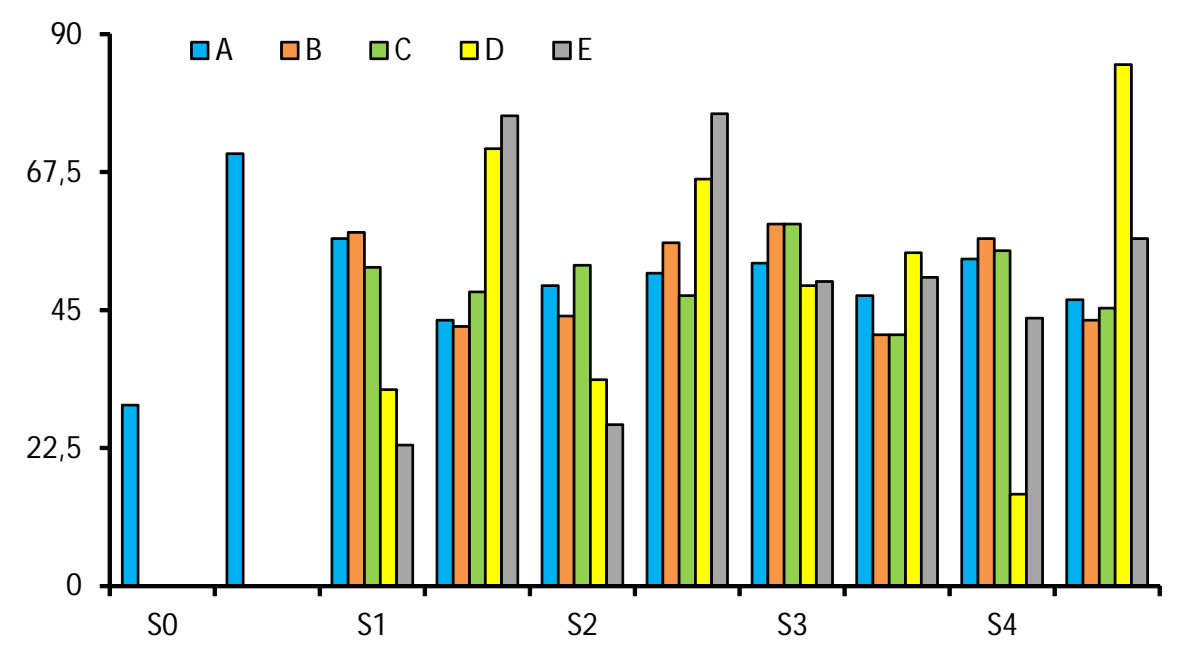

Figure 5. Phagocytosis index before (So) and after (S1-S4) of KHV-Aero vaccination.

pared with a single infection (Bradley \& Jackson, 2008). Coinfection models need to be studied in order to design disease control strategies, especially effective vaccine designs (Lello et al., 2004).

The onset of antibody titer with KHV: A. hydrophila $1: 2$ resulted a higher titer than $1: 1$ and $2: 1$ of the vaccine composition. There was a synergistic interaction between both antigens. A. hydrophila as an antigen could improved immunogenicity and protective efficacy against both of KHV and A. hydrophila. This means that this combination vaccine may potentiate and broaden the immune response. During co-infections, pathogens can compete with each other for food resources or target infection sites in the same host. Pathogen can alter the immune response of the host against subsequent infections by other pathogens either by suppressing or boosting the immune system (Lello et al., 2004, Telfer et al., 2008). In this research, A. hydrophila acted as a boosting agent for KHV and developed synergistic effect to induce the immune system and increasing the antibody titer. A. hydrophila as a secondary pathogen triggers and modulates the host immune response in a positive sense for KHV. This also means that the bacterial infection had reactivated persistent KHV which led to a very fast occurring immune response of antibodies measurable by ELISA assay.

The results presented in Table 2 showed that $40 \%$ immunized fish in group-1 and II had developed a sufficient immunity to protect themselves against KHV. However, all of the fish $(100 \%$ had become KHV carriers. Protection against KHV seems to be associated with elevation of specific antibodies against the virus. According to Ronen et al. (2003), KHV specific antibody titer increased at $7^{\text {th }}$ days post-infection (dpi) and reached its peaks at $21^{\text {st }} \mathrm{dpi}$. The levels of anti$\mathrm{KHV}$ antibodies remained high in the vaccine injected group for a period of 1.5-2 months, after which there was an apparent gradual decline in antibody titer. In total, $100 \%$ of the immunized fish were protected against the challenged test suggest the presence of specific efficient memory cells. According to Perelberg et al. (2008), KHV can remain latent for a long periods of time inside the infected host, at least 35 weeks post infection. The persistent KHV in the host can be reactivated through temperature changes, e.g. non-permissive to a permissive level of water temperature. Thus, survived fish carrying KHV might serve as the KHV reservoir.

The immunity of fish in group-III and IV are indicated by the emergence of higher antibody titers than KHV negative and KHV carrier fish. The most significant result was that vaccinated fish which undergo challenged test showed no symptoms of the disease. The results showed that vaccination before fish were infected with KHV had little effect on carrier fish. Repeated samplings of vaccinated fish failed to reveal the condition of the carrier fish. This might indicate that fish which survive a natural outbreak of a wild type KHV can become carriers and spread the virus to vaccinated populations. If the fish are kept at low temperatures or exposed to temperature stress, it can induce the emergence of the disease again. Bergmann et al. (2004) and Eide et al. (2011) showed that virus in latent conditions can be indicated by the presence of latency in fish leukocytes that have been exposed to KHV. Eide et al. (2011) and Hilaire et al. (2005), who studied fish with this nature 
latency, found that the infected population was very small and the concentration of KHV was very low, only 1-5 virus particles were detected by PCR assay. Furthermore, Bergmann et al. (2011) stated that to be able to detect the carrier fish, the virus must be reactivated using temperature stress. Reactivation of the virus to a detected level could be less 3-4 days after going through stress inductions such as temperature, stocking density and feed as these treatments induce hormonal changes in fish. Eide et al. (2011) also stated that low temperature is one of the effective ways of reactivating viruses.

Vaccination plays a role in forming immunological memory which offer a long-term protection. In salmonids, according to McHeyzer-Williams et al. (1999), there is a response from memory $B$ cells that is lower than in mammals. Furthermore, according to $\mathrm{Ma}$ et al. (2013), the thymus organ contributes to a logarithmic increase in antibody titers if the re-infection occcurs. However, revaccination (booster) increases the antibody titer arithmetically compared with the first immunization. The results of this study are in accordance with that of O'Connor et al. (2004) and Manz et al. (1998) were the diversity and duration of the limited KHV antibody response after vaccination may be caused by physiological conditions of fish which are not as advance as in mammals and the internal environment of the body related to chemokines, cytokines, and cell-to-cell interaction in the kidney anterior. Therefore, revaccination is necessary, so if an outbreak re-occurs, the vaccines will trigger the formation of logarithmic antibodies.

Vaccination programs must be carried out comprehensively to prevent outbreaks of infectious diseases. Vaccination needs to be done at the right time to maintain protective conditions starting from the initial maintenance until fish are harvested. This strategy can help fish farmers to maintain the fish's health and thus increase their production. Some notable immunologic differences exist among the presently available single-disease vaccines and a cocktail vaccine. Using a single vaccine induces earlier immune response after the first dose. Contrastingly, a combination vaccine gives higher antibody levels after the second and third doses, compared with a single vaccine. The most interesting but not yet explained is the difference in the level of immune response when a combination of the KHV vaccine and A. hydrophila is applied. Although A. hydrophila helps increase KHV antibody titers, its level is still higher than KHV. The level of antibodies with the same or higher position must be studied.

\section{CONCLUSION}

The combination vaccine of KHV: Aeromonas hydrophila $1: 2$ and vaccine volume of $3 \mathrm{~mL}$ via oral application is effective in decreasing mortality of koi and common carp from KHV and A. hydrophila coinfection. The combination vaccine simplifies the immunization schedule, which increase the overall health of cultured fish, benefits fish farmers with lower cost production and service extension officers.

\section{ACKNOWLEDGEMENTS}

This research was funded by the Annual National Budget of 2016 of the Research Institute for Freshwater Aquaculture and Fisheries Extension. The authors acknowledge technicians at the Research Station of Fish Health Control Depok for their technical assistance during the research.

\section{REFERENCES}

Bergmann, S.M., Fichtner, D., Dauber, M., Teifke, J.P., Bulla, V., \& Dresenkamp, B. (2004) KHV detection methods: Possibilities and limits. $X$. cooperative meeting of Swiss, German and Austrian EAFP branches, September $8^{\text {th }}$-10th, Stralsund, Germany, Proceedings, p. 57-62.

Bergman, S.M., Kempter, J., Sadowski, J., \& Fichtner, D. (2006). First detection, confirmation and isolation of koi herpesvirus (KHV) in cultured common carp (Cyprinus carpio L.) in Poland. Bulletin of the European Association of Fish Pathologists, $26,97$.

Bergmann, S.M. \& Kempter, J. (2011). Detection of koi herpesvirus (KHV) after reactivation in persistently infected common carp (Cyprinus carpio L.) using non-lethal sampling methods Bulletin of the European Association of Fish Pathologists, 31, 92-104.

Bergmann, S.M., Wang, Q., Zeng, W., Li, Y., Wang, Y., Matras, M., Reichert, M., ....., \& Kielpinska, J. (2017). Validation of a KHV antibo dy enzyme-linked immune sorbent assay (ELISA). J. of Fish Dis., DOI:10.1111/ffd.12621.

Bradley, J.E. \& Jackson, J.A. (2008). Measuring immune system variation to help understand host-pathogen community dynamics. Parasitology, 135, 807823.

Cox, F.E.G. (2001). Concomitant infections, parasites and immune responses. Parasitology, 122, S23S38. 
Eide, K.E., Miller-Morgan, T., Heidel, J.R., Kent, M.L.; Bildfell, R.J., Lapatra, S., Watson, G., \& Jin, L. (2011). Investigation of koi herpesvirus latency in koi. J. Virol., 85, 4954-4962.

Haenen, O.L.M., Way, K., Bergman, S.M., \& Ariel, E. (2004). The emergence of koi herpesvirus and its significance to European aquaculture. Bull. Eur. Ass. Fish Pathol., 24(6), 293.

Kotob, M.H., Amal, M.N.A., Shohaimi, S., Zamri-Saad, M., \& Siti-Zahrah, A. (2016). Associations of water quality and bacteria presence in cage cultured red hybrid tilapia, Oreochromis niloticus $\times 0$. mossambicus. Aquac. Rep., 4, 57-65.

Lello, J., Boag, B., Fenton, A., Stevenson, I.R., \& Hudson, P.J. (2004). Competition and mutualism among the gut helminths of a mammalian host. Nature, 428, 840-844.

Lusiastuti, A.M., Textor, M., Helga, H.S., Akineden, 0., \& Szchoeck, M. (2012). Short communication: The occurrence of Streptococcus agalactiae sequence type 261 from fish disease outbreaks of tilapia Oreochromis niloticus in Indonesia. Aquaculture Research, DOI:10.1111/are.12069.

Ma, C., Ye, J., \& Kaattari, S.L. (2013). Differential compart mentalization of memory B cells versus plasma cells in salmonid fish. Eur. J. Immunol., 43, 360-3670. DOI:10. 1002/eji.201242570.

Manz, R.A., Lohning, M., Cassese, G., Thiel. A., \& Radbruch, A. (1998). Survival of long lived plasma cells is independent of antigen. Int. Immunol., 10, 1703-1711. DOI:10.1093/intimm/10.11.1703.

McHeyzer-Williams, M.G. \& Ahmed, R. (1999). B cell memory and the long-lived plasma cell. Curr. Opin. Immunol., 11, 172-179. DOI:10.1016/S09527915(99) 80029-6.

Monaghan, S.J., Thompson, K.D., Bron, J.E., Bergmann, S.M., Jung, T.S., Aoki, T., Muir, K.F., Dauber, M., Reiche, S., Chee, D., Chong, S.M., Chen, J., \& Adams, A. (2016). Expression of immunogenic structural proteins of cyprinid herpesvirus 3 in vitro assessed using immunofluorescence. Veterinary Research, 47, 8.

Nakajima, M., Yokoi, T., Mizutani, M., Kinoshita, M., Funayama, M., \& Kamataki, T. (1999). Genetic polymorphism in the 5 '-flanking region of human CYP1A2 gene: Effect on the CYP1A2 inducibility in humans. J. Biochem., 125(4), 803-808.

Nicholson, P., Fathi, M.A., Fischer, A., Mohan, C., Schieck, E., Mishra, N., Heinimann, A., ..... \& Jores, J. (2017). Detection of tilapia lake virus in Egyptian fish farms experiencing high mortalities in 2015. J. Fish Dis., 40, 1925-1928.
O'Connor, B.P., Raman, V.S., Erickson, L.D., Cook, W.J., Weaver, L.K., \& Ahonen, C. (2004). BCMA is essential for the survival of long-lived bone marrow plasma cells. J. Exp. Med., 199, 91-98. DOI:10.1084/ jem.20031330.

Reed, L.J. \& Muench, H. (1938). A simple method of estimating fifty per cent endpoints. American Journal of Epidemiology, 27(3), 493-497.

Ronen, A., Perelberg, A., Abramowitz, J., Hutoran, M., Tinman, S., Bejerano, I., Steinitz, M., \& Kotler, M. (2003). Efficient vaccine against the virus causing a lethal disease in cultured Cyprinus carpio. Vaccine, 21, 4677-4684.

Roberson, B.S. (1990). Bacterial agglutination. In Stolen, J.S., Fletcher, T.C., Anderson, D.P., Roberson, B.S., \& van Muiswinkel, W.B. (Eds.). Techniques in fish immunology. New Haven, N.J.: SOS Publications, p. 81-86.

Schmid, T., Gaede, L., Böttcher, K., Bräuer, G., Fichtner, D., Beckmann, R., Speck, S., ...., \& Truyen, U. (2016). Efficacy assessment of three inactivated koi herpes virus antigen preparations against experimental challenge virus infection in common carp. Journal of Fish Disease, 39, 1007-1013.

Sunarto, A., Taukhid, Rukyani, A., Koesharyani, I., Supriyadi, H., Huminto, H., Agungpriyono, D.R., ....., \& Prayitno, S.B. (2002). Field investigations on a serious disease outbreak among koi and common carp (Cyprinus carpio) in Indonesia. Paper presented in 5th Symposium on Diseases in Asian Aquaculture, 24-28 November 2002, Gold Cost, Australia, 56 pp.

Sunarto, A. \& Cameron, A. (2005). Response to mass mortality of carp: an Indonesian experiences In: Regional Workshop on Preparedness and response to Aquatic Animal Health Emergencies in Asia. Subasinghe, R.P. \& Arthur, J.R. (Eds,). FAO Fisheries Proceeding, 4, 87-106.

Surachetpong, W., Janetakit, T., Nonthabenjawang, N., Tattiyapong, P., Sirikanchana, K., \& Amonsin, A. (2017). Outbreaks of tilapia lake virus infection, Thailand, 2015-2016. Syst. Appl. Microbiol., 28, 242-264.

Telfer, S., Birtles, R., Bennett, M., Lambin, X., Paterson, S., \& Begon, M. (2008). Parasite interactions in natural populations: Insights from longitudinal data. Parasitology, 135, 767-781.

St-Hilaire, S., Beevers, N., Way, K., Le Deuff, R.M., Martin, P., \& Joiner, C. (2005). Reactivation of koi herpesvirus infections in common carp Cyprinus carpio. Dis. Aquat. Org., 67, 15-23. 
van Regenmortel, M.H.V., Fauquet, C.M., Carstens, E.B., Estes, M.K., Lemon, S.M., Maniloff, J., Mayo, M.A., ...., \& Pringle, C.R. (2000). Virus taxonomy. Seventh Report of the International Committee on Taxonomy of Viruses. San Diego, CA, USA: Academic Press, $50 \mathrm{pp}$.

Yuasa, K., Sano, M., Kurita, J., \& Lida, T. (2005). Improvement of a PCR method with the Sph 1-5 primer set for the detection of koi herpesvirus (KHV). Fish Pathology, 40, 37-39.

Yasumoto, S., Kuzuya, Y., Yasuda, M., \& Miyazaki, T. (2006). Oral immunization of common carp with a liposome vaccine fusing koi herpesvirus antigen. Fish Pathology, 41(4), 141-145. 